\title{
F2 Gene Product
}

National Cancer Institute

\section{Source}

National Cancer Institute. F2 Gene Product. NCI Thesaurus. Code C101803.

A protein encoded by the F2 gene. 